
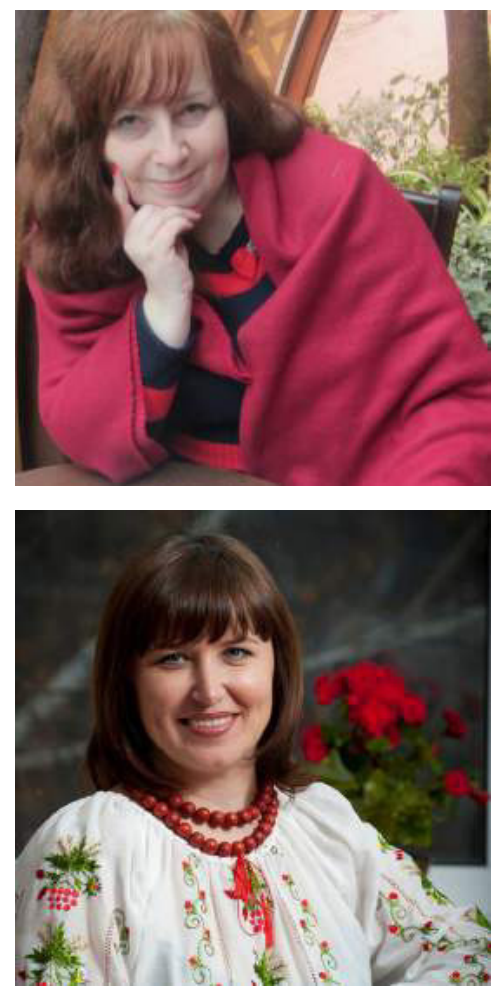

\section{Олена Бровко,}

доктор філологічних наук, професор,

Київський університет імені Бориса Грінченка

(м. Київ)

\author{
Olena Brovko, \\ Doctor of Philological Sciences, Professor, \\ Borys Grinchenko Kyiv University \\ (Kyiv) \\ o.brovko@kubg.edu.ua
}

\author{
Наталія Богданець-Білоскаленко, \\ доктор педагогічних наук, доцент, \\ Київський університет імені Бориса Грінченка \\ (м. Київ)
}

\author{
Natalia Bogdanets-Biloskalenko, \\ Doctor of Pedagogical Sciences, Associate Professor, \\ Borys Grinchenko Kyiv University \\ (Kyiv) \\ n.bohdanets-biloskalenko@kubg.edu.ua
}

УДК 821-161.2-31.09. ББК 83.3 (4УКР)

\title{
КУЛЬТУРНИЙ ЛАНДШАФТ ХУДОЖНЬОГО ТЕКСТУ ЯК ВИЯВ ЕТНІЧНОЇ ІДЕНТИЧНОСТІ: ТЕХНОЛОГІЯ ВИВЧЕННЯ
}

\section{CULTURAL LANDSCAPE OF A FICTION TEXT AS AN MANIFESTATION OF ETHNIC IDENTITY: TECHNOLOGY OF STUDY}

у статті описується роль культурного ландшафту художнього тексту як вияву етнічної ідентичності у вивченні української літератури.

Метою статті $\epsilon$ розкриття художньої специфіки культурного ландшафту як чинника етнічної ідентичності в літературному тексті. Автори розкривають етно-національні текстові проекції ідентичностей у художньому дискурсі. Акцентується увага на тому, що модель інтерпретації художньої літератури крізь призму ідентичностей, відрефлектованих у контексті міждисциплінарних студій, має потужний виховний потенціал. Аналізується етнокультурна, аксіологічна та художня специфіка текстів І. Чендея “Скрип колиски», Ю. Мейгеша «Фінал драми», Т. Прохаська «НепрОсті».

Методологічними засадами дослідження є праці Ч. Тейлора «Джерела себе», Е. Д. Сміта «Національна ідентичність», студії Ф. Фукуями «Ідентичність і міграція», Ю. Веденіна «Нариси з географії мистецтва», Н. Стракаускайте «Культурний ландшафт поблизу Куршської лагуни» та ін.

Отже, при вивченні художньої літератури важливими є адаптаційні та інтеграційні практики авторів, які в мистецькому полі описали, проаналізували, осмислили проблеми ідентичності, що може служити основою для створення моделей і сценаріїв позитивної культурної реконструкції та формування громадянської ідентичності в сучасній Україні.

Ключові слова: культурний ландшафт, геопоетика, етнічна ідентичність, технологія вивчення, українська література, Іван Чендей, Юрій Мейгеш, Тарас Прохасько.

This article describes the ethnic-cultural aspect of the problem of cultural landscape in Ukrainian literature. The article is devoted to the reflection of the text «cultural landscape». Based on an review of the literature, the notion "cultural landscape», and close to it the concept «ethno-cultural» landscape. The article deals with the analysis of polyphony in modern prose work. Intragenre possibilities of short story us a small epic form and result of nongenre recations are examined in the investigation in works of «Skryp kolysky» by Ivan Chenday, «Final dramy» by Yuri Meygesh, «NeprOsti» by Taras Prokhas'ko. In the article an attempt to comprehend the identity problem in Ukrainian literature of the late XX-XXI century. Ivan Chenday's, Yuri Meygesh's and Taras Prokhas'ko's works of different periods that present the identity problem of personality. Underlined narrative hierarchies' nuance peculiarities at the corresponding levels of fiction communication contribute to exposure of artistic potential of prose works. Narrative strategies of the Ukrainian prose allow speaking about the close contact 
between modern and traditional ways of the text organization. In the novel «NeprOsti» projection «rustic / modern» acquires predominantly aesthetic and psychological manifestations. Local space and limited geo-cultural landscape inspires individual mythology. These tendencies are seen through-out the modern Ukrainian culture.

The cultural parameters of the artistic space based on the concept of «cultural landscape» have been identified. The mechanisms of forming of ethnic-cultural identity are also analysed - cultural landscape and artistic space.

Heuristic means of the geopoetic paradigm for the literature studies are pointed out.

Keywords: cultural landscape, ethnic identity, geopoetic, technology of study, Ukrainian literature, Ivan Chenday, Yuri Meygesh, Taras Prokhas'ko.

В статье описывается роль культурного ландшафта художественного текста как выражения этнической идентичности в изучении украинской литературы.

Целью статьи является раскрытие художественной специфики культурного ландшафта как фактора этнической идентичности в литературном тексте. Авторы раскрывают этно-национальные текстовые проекции идентичностей в художественном дискурсе. Акцентируется внимание на том, что модель интерпретации художественной литературы сквозь призму идентичности, осмысленная в контексте междисциплинарных студий, имеет мощный воспитательный потенциал. Анализируется этнокультурная, аксиологическая и художественная специфика текстов И. Чендея «Скрип колыбели», Ю. Мейгеша «Финал драмы», Т. Прохасько «Непростые».

Методологической основой исследования являются труды Ч. Тейлора «Источники себя», Е. Д. Смита «Национальная идентичность», студии Ф. Фукуямы «Идентичность и миграция», Ю. Веденина «Очерки по географии искусства», Н. Стракаускайте «Культурный ландшафт около Куршского залива» и др.

Таким образом, при изучении художественной литературы важны адаптационные и интеграционные практики авторов, которые в художественном поле описали, проанализировали, осмыслили проблемы идентичности, что может служить основой для создания моделей и сценариев положительной культурной реконструкции и формирования гражданской идентичности в современной Украине.

Ключевые слова: культурный ландшафт, геопоэтика, этническая идентичность, технология изучения, украинская литература, Иван Чендей, Юрий Мейгеш, Тарас Прохасько.

Постановка проблеми в загальному вигляді та її зв'язок з важливими науковими та практичними завданнями. Одним із актуальних напрямів сучасного вивчення художньої літератури є геопоетика. Міждисциплінарний характер гуманітарного знання дає право спиратися на закони й закономірності, відкриті також у соціальному, природничому знанні, у точних науках, де специфіка ідентичностей є значущим предметом вивчення. Ця проблема не $є$ цілком усвідомленою в українській гуманітаристиці. Ї̈̈ можна осмислити, відштовхнувшись від світоглядної картини в класичних дослідженнях Ч. Тейлора «Джерела себе», Е. Д. Сміта «Національна ідентичність», есеях Е.Саїда «Думки про вигнання», К. Гайна «Два розмисли про мандри й вигнання», сучасної студії Ф. Фукуями «дентичність і міграція» та ін. Ці роботи є теоретико-методологічним підґрунтям осмислення ідентичності і глобалізації як модусів сучасного світу в аспекті геопоетики. Увагу дослідників привертає ролі антропогенного чинника в довкіллі, аналіз урбаністичного і рустикального, взаємодії сакрального та світського ландшафтів, ментальних карт тощо [1]. Ю. Веденін зауважував, що поетична географія - це культурний ландшафт, або система культурних ландшафтів, які відтворені в художніх образах, або використовуються в ролі символів у творчості поета» [2, с. 134]. Як відомо, культурний ландшафт - це частина довкілля, не тільки трансформованого під впливом людини, а й узагальненого до статусу символу.

Формування мети статті. Метою статті є розкриття художньої специфіки культурного ландшафту як чинника етнічної ідентичності в літературному тексті. Об'єктом дослідження обрано тексти І. Чендея, Ю. Мейгеша та Т. Прохаська. Предметом дослідження $€$ етно-національні текстові проекції ідентичностей у художньому дискурсі. За твердженням литовської дослідниці Н. Стракаускайте, саме пам'ять і місце через ландшафт дають змогу поєднати в єдине ціле локальні, етнічні та глобальні аспекти [7, с. 11]. У цій статті пропонуємо при вивченні української літератури звернутися до характеристики культурного ландшафту в мистецькому просторі письменників різних поколінь, об'єднаних художнім експериментуванням у творенні карпатського тексту.

Виклад основного матеріалу дослідження з повним обґрунтуванням отриманих наукових результатів. І. Чендей народився в смт Дубове на Тячівщині й у своїй прозі витворив яскравий світ Закарпаття. Дослідники М. Васьків та В. Бойко наголошують на аналогіях між Забережжю І. Чендея, Йокнапатофою В. Фолкнера і Макондо Ґ.Ґ. Маркеса. Саме потужний виховний потенціал характерний для художнього прийому обрамлення як сюжетно-композиційної єдності в романі І. Чендея «Скрип колиски». У романі, який складається з 36 розділів і епілогу, глави «Що розповіла пляшка коньяку» та «Монолог пляшки коньяку» створюють обрамлення, що увиразнює ідейний зміст твору. Виноградна лоза - поширений бароковий символ, що набув у творі І. Чендея сучасного авторові семантичного наповнення. Зав'язка наскрізної сюжетної лінії міститься в новелі «Перше таїнство», де старий виноградар Петро Миколайович Головачук розповідає про культуру виготовлення і споживання вина кореспонденту, націленому на антиалкогольний репортаж. «- Ні, ні. Не для того воно садиться і росте, квітне і зав'язується, аби від нього захмелений глум і біда! Воно для здоров'я і радості! - сивий тепер наче сказав усе.

- Правду кажете. Природа його для здоров'я і радості дає, а хто для чого здатний, для того собі і бере... Один тільки для радості, а скільки їх для смутку і біди гіркої... - Гриць вусиками стригонув» [6, с. 15]. 
«Скрип колиски» І. Чендея - історії з життя закарпатських виноградарів, праця яких хоч і має прадавні традиції й є справжнім таїнством, та, водночас результат цієї праці нівечить особистості, шкодить людським взаєминам, руйнує сім'ї та здоров'я.

Творчість Ю. Мейгеша репрезентує яскраві зразки літературної мозаїки. Ю. Мейгеш народився у Великому Раковці (нині - Іршавський район Закарпатської області). До структури твору «Верховинці» органічно входить щоденник поета Бородчака, який подає свою версію подій на Прикарпатті за часів діяльності Августина Волошина. Роман «Сьогодні і завжди», за авторським жанровим маркуванням, є власне літературною мозаїкою. Геміністичною проекцією на взаємини філософа Василя Петровича Шестича й Калинки є історія кохання юродивих Піріки й Мішка. Складністю композиції відзначаються й романи Ю. Мейгеша «Голгофа» та «Стихія» В. Поп асоціює епіку письменника з химерною прозою, наголошуючи: «Романи Ю. Мейгеша можна зарахувати до так званих «химерних» творів з їх довільною часово-просторовою інваріантністю, порушенням традиційної композиції, законів сюжету. Пригадати хоча б такі зразки цього жанру, як романи М. Булгакова «Майстер і Маргарита» О. Ільченка «Козацькому роду нема переводу...» чи Ю. Щербака «Хроніка міста Ярополя» [4, с. 89]. У структурі роману Ю. Мейгеша «Фінал драми» сцени репетиції драмивистави «Легенда про любов» дають змогу письменникові, до речі, історикові за освітою, всебічно розкрити проблему влади на матеріалі подій різних історичних періодів. Сюжетні лінії життя акторів, особиста життєва драма Павлюка переплітаються з відтвореними на сцені епізодами з життя Сократа і Спартака, Робесп'єра і Марата, Яна Гуса і Джордано Бруно, Кампанелли і Монтеск'є. В усі історичні епохи на авансцені опиняються Вождь, Жрець, Борець і Жінка. Письменник не трактує цю проблему спрощено, а намагається осмислити феномен влади в його етикоморальних і політологічних вимірах, художньо відтворити всю складність переродження борця-правдошукача на владного деспота. «У романі «Фінал драми», - пише В. Поп, - автор поєднав форму драматургічного розвитку дії з прозово-оповідними та елементами психологічної прози, що знову таки виявляє амплуа Ю. Мейгеша 3 тяжінням до оновлення жанру роману, до збагачення прозових жанрів елементами інших родів і видів літератури, та й ширше - інших мистецтв» [4, с. 89]. Частково витримано формальні ознаки драми, а саме: поділ на дії й картини, уведення інтермедій, діалогічна композиційна форма, розгорнуті ремарки, однак у романі «Легенда про любов» є складною метатекстуальною конструкцією, функціональне призначення якої хоч і визначається жанровими можливостями драми, проте передусім текст п'єси важливий як вдалий композиційний прийом. Поперше, задум п'єси належить дядькові Івану, про що кілька разів згадується у творі. По-друге, Антон Петрович Павлюк - автор п'єси і центральний персонаж роману. По-третє, свою режисерську версію пропонує Семен Романович Юрченко. По-четверте, актори подають своє розуміння «Легенди про любов». Водночас гра акторів постає в авторській оцінці, а окремі епізоди п'єси перемежовуються з життєвими історіями працівників театру, передусім з родинною драмою Павлюка. Сюжетно-композиційним обрамленням слугує очікування компетентної особи чи комісії. «Ну, що тут не так? - доскіпувався Антон Петрович, - Дикість, цивілізація... і цей символічний рух людей до щастя... Безконечність?.. А хіба може бути кінець? - запитував себе, уже й сам починаючи сумніватися в чомусь. Чи, може, й справді я чогось не розумію? Хтось там розуміє, а я ні» [3, с. 3]. Звістка про заборону вистави стає рушієм драматичної розв'язки роману, у якому локальний культурний ландшафт розгортається в полікультурному просторі.

У локалізованому просторі Карпат відбувається дія в романі-есе відомого письменника з Івано-Франківська Т. Прохаська «НепрОсті», де сюжет розгортається між 1913 і 1951 роками. «Чому завжди війна?»- ця фраза з роману знову повертає увагу читача до думки про циклічність буття і запитань «що було, якби...?». Якби перемогла Карпатська Україна, якби державність спочатку утвердилася в Ялівці - українському острівці Центральної Європи: «Моє місце завжди опинятиметься в центрі європейської історії, бо в цих краях історія у різних формах сама приходить на наші подвір'я» [5].

У цьому романі-есе уважний читач помітить зв'язок зі світовою мистецькою традицією магічного реалізму, українською химерною прозою. Художньою домінантою твору є жанрово-стильові маркери новонародженого канону літературної історичної альтернативістики, риси новоміфологізму або т.зв. «ландшафтного письма». Попри позірну моновекторність оцінок, означені риси свідчать про множинність інтерпретацій, глибину підтексту цієї художньої знахідки, що захоплює читача з перших сторінок і тримає запитанням «що буде далі?», відсилає до принципу циклічного руху міфологічної оповіді - історії містечка Ялівця, в якому химерно переплітаються цивілізаційні і культурні, рустикальні і модерні коди. Архаїка, яка зберігається у згадках про «непростих» чи «земних богів», здатна оновлюватися, актуалізуючи національні версії світової міфології.

Текст Т. Прохаська вирізняється увагою до міфологізації свідомості, адже наративні версії різних сценаріїв української історії засвідчують потребу сучасної людини осмислити минуле своєї країни. Персонажі одночасно перебувають у подієвому світі, змальованому у творі, та міфологічному, що становить глибинний зміст оповіді і накладається на актуальний сюжет - формування національної ідентичності на території помежів'я, бо центральноєвропейський курорт Ялівець «знаходився в Українських Карпатах, а не просто в Чехо-Словацькій республіці. Але Станиславів, Львів і Арджелюджа опинилися за забороненою лінією на Чорногорі» [5]. Образ Українських Карпат в художньому світі Т. Прохаська сприймається як модель світоустрою, що тримається на осерді - власній ідентичності як умові існування впорядкованого світу і як альтернативному націєтворчому 
чинникові: «Українська держава можлива лише тоді, коли карпатський вектор стане основою їі геополітики, карпатська космогонія - моделлю ідеології, а самі Карпати - природним резерватом» [5].

Основний топос цього роману-есе - місто-дерево, місто-химера, де переплітаються, повторюючись, життя, де формується нова історіософія. Для героя роману й оповідача повернення в Ялівець, вибудуваний зі слів і думок, - це своєрідна дорожня карта митця як модель відкритої ним території. «Коли воює Південь з Північчю, а Схід із Заходом, то роблять це переважно в Центральній Європі, де Карпати і їхні річки. I найгірше, що може бути в такі часи, - виконувати роль мирного населення Карпат або стратегічно важливого пункту на півкілометровій топографічній мапі» [5]. Як бачимо, картографічні відмінності в семіотичному, вербальному сенсі від географічного світу як території («Карта не є територія» А. Коржибськи, «Карта перечитування» Г. Блума) інспірують актуальну реконструкцію і перевизначення ідентичності як проблеми.

Актуальність проблематики, оригінальність реалізації творчого задуму, емоційно-естетична наснаженість візуальних образів, фрагментарність, монтажність композиції як засіб кінопоетики в «НепрОстих» привертають увагу читачів. У «НепрОстих» Т. Прохаська на високому художньому рівні осмислюються дві тенденції сьогодення: збереження власної національної своєрідності та відкритість до полікультурного простору.

Висновки і перспективи подальших досліджень. Отже, при вивченні художньої літератури важливими $€$ адаптаційні та інтеграційні практики митців, які в мистецькому полі описали, проаналізували, осмислили проблеми ідентичності, що може служити для створення моделей і сценаріїв позитивної культурної реконструкції та формування громадянської ідентичності в сучасній Україні. Пропонована студія є частиною дослідження, спрямованого на вироблення моделі інтерпретації художньої літератури крізь призму ідентичностей, відрефлектованих у контексті міждисциплінарних студій.

1. Антропологія простору. Том. 1. Культурний ландшафт Києва та околиць / За наук. ред. М. Гримич. - К. : Вид-во «Дуліби», 2017. - $316 \mathrm{c}$.

2. Веденин Ю. А. Очерки по географии искусства / Ю. А. Веденин. - М. : Рос. НИИ культур и природ. наследия, 1997. - 224 с.

3. Мейгеш Ю. В. Фінал драми / Юрій Мейгеш. - К. : Укр. письм., 1989. - 239 с.

4. Поп В. Юрій Мейгеш. Життя і творчість : Літ.-крит. нарис / Василь Поп. - Ужгород : Патент, 1997. - 160 с.

5. Прохасько Т. НепрОсті [Електронний ресурс] / Тарас Прохасько. - Івано-Франківськ : Лілея-НВ, 2006. - 140 с. - Режим доступу: http://www.azh.com.ua/lib/taras-prokhasko-neprosti.

6. Чендей І. Скрип колиски: [роман] / Іван Чендей. - Ужгород : Карпати, 1987. - 412 с.

7. Strakauskaitè N. Kultūros kraštovaizdis prie Kuršių marių / Nijolè Strakauskaitè. - Klaipèda : Klaipèdos universiteto leidykla, 2010. - 255 c.

\section{Reference}

1. Antropologiya prostoru. Tom. 1. Kul'turny'j landshaft Ky'yeva ta okoly'cz'. K., 2017. 316 c.

2. Vedenin Ju. A. Ocherki po geografii iskusstva. M., 1997. 224 s.

3. Meygesh Y. Final dramy. K., 1989. 239 s.

4. Pop V. Yurij Mejgesh. Zhyttya i tvorchist': Lit.-kryt. narys. Uzhgorod, 1997. $160 \mathrm{~s}$.

5. Prokhas'ko T. NeprOst'i. Ivano-Frankivs'k, 2006. $140 \mathrm{~s}$.

6. Chenday I. Skryp kolysky. Uzhgorod, 1987. $412 \mathrm{~s}$.

7. Strakauskaitex N. Kultuxros krasxtovaizdis prie Kursxiuu mariuu. Klaipeda, 2010. 255 s.

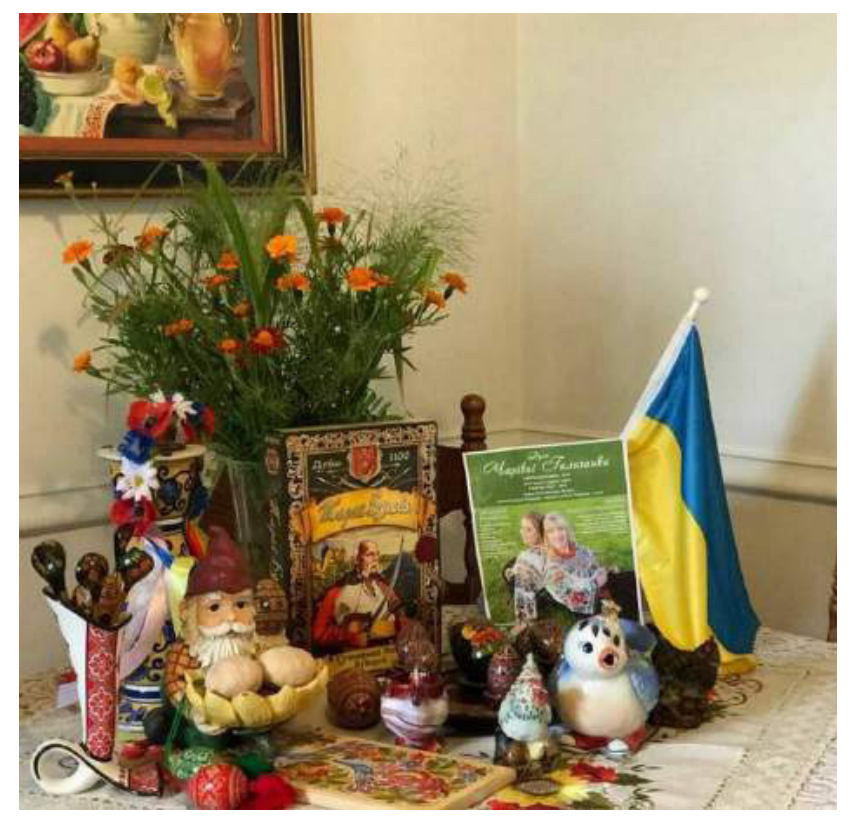

